\title{
INCREASING THE CORROSION RESISTANCE OF TURBINE
}

\author{
Hlushkova D. B. ${ }^{1}$, Bahrov V. A. ${ }^{1}$, Hrinchenko O. D. ${ }^{1}$, Stepanyuk A. I. ${ }^{1}$, \\ Hnatiuk A. A. ${ }^{1}$, Kalinina N. E. ${ }^{2}$ \\ ${ }^{1}$ Kharkiv National Automobile and Highway University, Kharkiv, Ukraine \\ ${ }^{2}$ Oles Honchar Dnipro National University Dnipro, Ukraine
}

\begin{abstract}
The reliability of the vane apparatus of steam turbines largely determines the operation of the turbine as a whole. The results of scientific research indicate that the surface operation of the blades in the wet - steam flow is caused by a combination of corrosion and drip erosion. The presence of chemical elements and compounds in the working fluid intensifies the process of blade wear. The $\mathrm{pH}$ value of the working environment, which can fluctuate significantly during operation, has a significant effect on the wear characteristics. The influence of methods of strengthening the leading edges of steam turbine blades made of steel is analyzed 15X11MФ on corrosion resistance. Corrosion tests of blade samples were carried out, the inlet edges of which were strengthened in three ways: high current amplification, electrospark alloying with T15K6 alloy, electrospark alloying with steel $15 X 11 M \Phi$ According to the results of the tests, the layer strengthened by hardening by high-frequency currents has the lowest corrosion rate, the layer strengthened by electrospark alloying with T15K6 hard alloy has the highest. The corrosion rate of the layer reinforced by electrospark alloying of steel $15 H 11 M F$ is 2.1 less than that of the layer reinforced with T15K6 alloy.
\end{abstract}

Keywords: turbine blades, corrosion, erosion, electrospark alloying, hardened layer.

\section{Articulation of Issue}

In the complex of issues that determine the reliability and efficiency of turbines in thermal and nuclear power plants, the reliability of the vane apparatus - the most expensive element of the turbine, which is most often damaged - is of great importance. The working conditions require high hardness of the leading edges, high erosion resistance, no negative influence of the parameters of forming a protective coating on mechanical properties, and high corrosion properties. [1]

This problem is especially acute for the working blades of the last stages low-pressure cylinders, the corrosion and erosion wear of which determines the service life of turbines.

Corrosion damage to the blades is observed to varying degrees on the equipment of all turbine types. This is due to the fact that the steam environment always contains corrosive substances, the amount of which depends on the rate of damage development.

The corrosion damage in the form of pitting and honeycombs is a stress concentrator. Depending on the size, number and location, the working blades and disks are destroyed. With significant metal losses due to corrosion, the strength characteristics of the blades decrease and the natural vibration frequencies change. The formation of such damage during peration usually occurs on steps located in the phase transition zone and less often in the wet steam zone. During prolonged downtime of the turbine, pitting and ulcers can form along the entire flow part of the turbine (standstill corrosion), as well as near extractors and drains. This is due to condensation of steam getting the surface of the flow part of a non-working turbine through loosely closed or defective fittings of drains, extractors, etc.

Analysis of the results of surveys of the disks and turbine blade apparatus metal showed that significant corrosion damage to the disks and working blades during operation occurs only at the stages of turbines operating in the phase transition zone (the wet steam zone from the state of dry saturated steam to a humidity of about 6\%). Such corrosion damage to the discs and working blades during the operation of the turbine in the area of superheated steam was not detected.

The results of scientific studies performed in recent years [2-3] indicate that the surface operation of working blades in a wet steam flow is caused by a combination of corrosion and water droplet erosion (fig. 1).

The presence of chemical elements and compounds in the working fluid intensifies the process of erosion wear. A significant influence on the characteristics of erosion wear makes the $\mathrm{pH}$ value of the working medium, which can vary significantly during operation. 


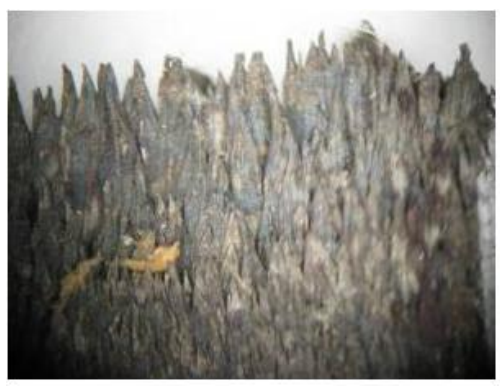

a

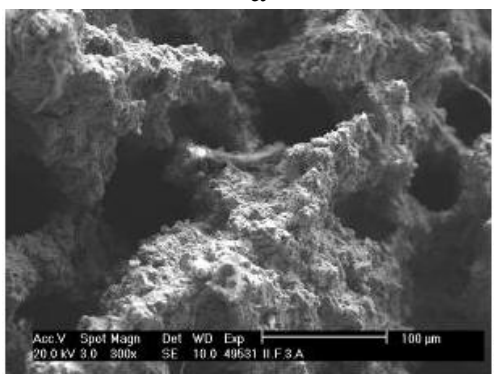

c

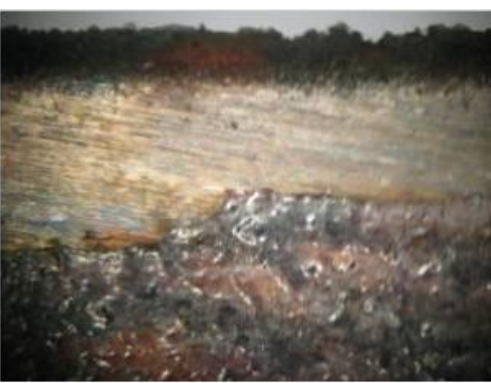

b

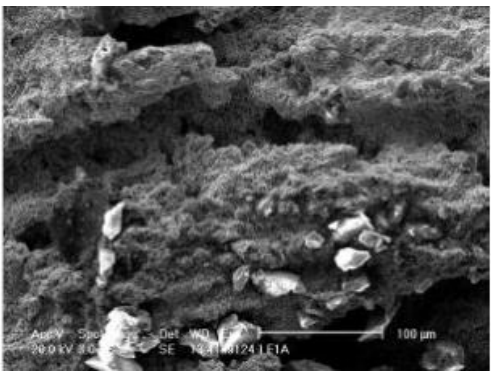

d

Fig. 1. Structure of destruction zones of the leading edges of steam turbine blades of the last stages of low pressure cylinders during operation: $a, b-\times 2 ; c, d-\times 200$

Due to the consequences of corrosion and erosion destruction of the leading edges of the blades for the service life and performance of the turbine, it is necessary to establish mechanisms for degradation of the blade surface. A complex phenomenon, such as the destruction of the surface of the blade feather as a result of exposure to aggressive environmental factors, requires experimental research. One of the ways to reduce the erosion wear of the working blades is to increase the efficiency of anti-erosion properties by forming protective layers on the leading edges that can withstand the influence of operational factors.

\section{Analysis of publications}

Analysis of publications [5-7] showed that the problem of erosion and corrosion damage to working blades exposed to a complex range of low-cycle and high-frequency thermo mechanical loads during operation is relevant for more than 70 years, but to date it has been partially solved, so research in the field of protective layers of blades is an important aspect in solving this problem.

The purpose of the article is to study the condition of the surface layer of the working blade of a steam turbine made of 15X11M $\Phi$ steel, after hardening with high frequency currents, electric-flash alloying with T15K6 alloy, electric-flash alloying with 15X11MФ-Ш steel, to assess the corrosion resistance of the reinforced areas of the blade feather, to perform a comparative assessment of the protective layer properties.

\section{Research results and discussion}

In order to determine the corrosive effect of the medium, water samples were taken at the nuclear power plant K 220-44-2 turbine. The acidity value of the samples and the electrical conductivity of water are given in Table.1.

In all selected samples, $\mathrm{pH}>7$, the acidity values vary from 9.4 to 11.55 , which corresponds to the $\mathrm{pH}$ values of an alkaline (basic) solution. The electrical conductivity varies quite significantly: in samples 1-4 the conductivity varies from $210 \mathrm{G}$ to $810 \mathrm{G}$, in samples 5-9 - from $14.5 \mathrm{G}$ to $22.5 \mathrm{G}$, which indicates the heterogeneity of water in terms of impurity content. The anion content in the obtained water samples was also determined.

The measurement results showed an extremely large number of metal ions, and the presence of $\mathrm{Al}, \mathrm{Fe}, \mathrm{Cr}, \mathrm{Ni}, \mathrm{Cu}$, and $\mathrm{Zn}$. Cr, W was found using the electromagnetic trap, and the content of them can only be the result of some corrosion, erosion of the blades, which is quite logical: the blades are made of 15X11MФ chromium-nickel steel, the leading edges are reinforced with an T15K6 alloy comprising tungsten carbide.

The presence of metal impurities in water samples indicates the erosion processes during the operation of the turbine blade apparatus. Nitrites and nitrates are present in ion concentrations in very small amounts. 
Table 1 - Results of measuring water acidity $(\mathrm{pH})$ and electrical conductivity

\begin{tabular}{|c|c|c|}
\hline $\begin{array}{c}\text { Sample } \\
\text { number }\end{array}$ & $\mathrm{pH}$ of water samples & $\begin{array}{c}\text { Electrical conductivity of water, } \mathrm{S}, \\
\mathrm{G}, \boldsymbol{\mu ~ \mathrm { S } \mathrm { cm } ^ { - 1 }}\end{array}$ \\
\hline 1. & 11.09 & 580 \\
\hline 2. & 10.34 & 235 \\
\hline 3. & 11.55 & 810 \\
\hline 4. & 10.31 & 210 \\
\hline 5. & 9.4 & 20.5 \\
\hline 6. & 9.7 & 14.5 \\
\hline 7. & 9.7 & 15.0 \\
\hline 8. & 9.81 & 22.5 \\
\hline 9. & 9.65 & 17.0 \\
\hline
\end{tabular}

In accordance with the obtained water quality results, $\mathrm{HN}_{3}$ corrosive medium with an acidity of $\mathrm{pH} 9.6$ was selected during the studies.

The study of samples from blades, the leading edge of which was reinforced by various methods: microwave quenching with subsequent tempering (sample 1), electrospark alloying (ESA) with traditional T15K6 alloy (sample 2), electrospark alloying with steel identical to the blade material, 15X11MФ-Ш (sample 3). The samples were taken from degree 5 blades made of 15X11MФ steel (fig. 2).

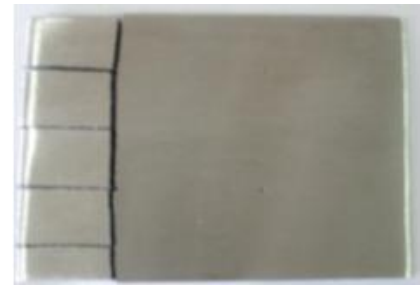

a

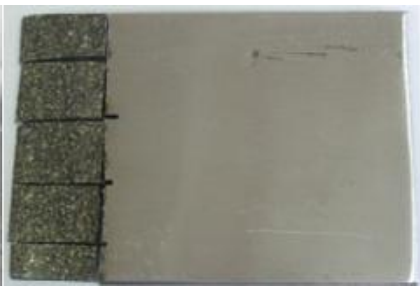

b

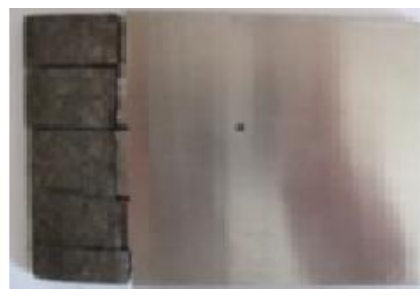

$\mathrm{c}$

Fig. 2. Type of test samples: $\mathrm{a}-$ sample $1 ; \mathrm{b}-$ sample $2 ; \mathrm{c}-$ sample 3

The study of the surface condition of the blade samples in the hardening zone was performed in two sections marked as "Position 1" and "Position 2". Part of the sample marked as "Position 1" was in a vapor medium, part of the sample marked as "Position 2" was immersed in an aqueous solution with an acidity of $\mathrm{pH}$ 9.6. The surface condition of the sample before testing was recorded using a SEM image.

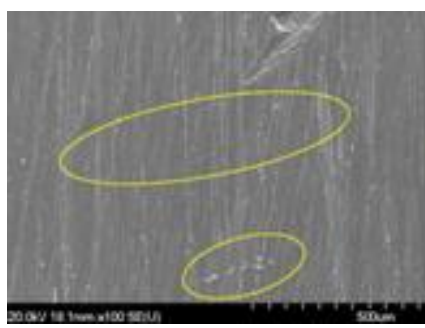

SEM images of microwave reinforced Sample 1 are shown in fig. 3 at magnifications of $\times 50$ and $\times 1000$ before exposure to a corrosive environment. The surface condition was studied after exposure for 28 days in an aggressive environment. This exposure time did not cause significant damage to the surface of the blade.

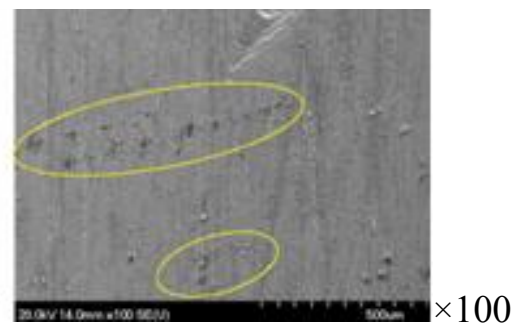

Fig. 3. Sample 1 Position 2: $\mathrm{a}$ - before the test for exposure to a corrosive environment; $\mathrm{b}-$ after the test

When examining the surface of a sample reinforced by ESA with alloy T15K6, it was found that the surface is very heterogeneous (fig.4), even with irregularities detected at lowresolution magnifications, there are holes (craters) on the treated surface. This is due to the 
fact that during electrospark alloying, local heating of the metal occurs and microscopic shrinkage shells are formed. Such relief is typical for this type of surface reinforcement.
Corrosion destruction occurs locally, mainly at the interface for the base metal of the blade (fig. 5).
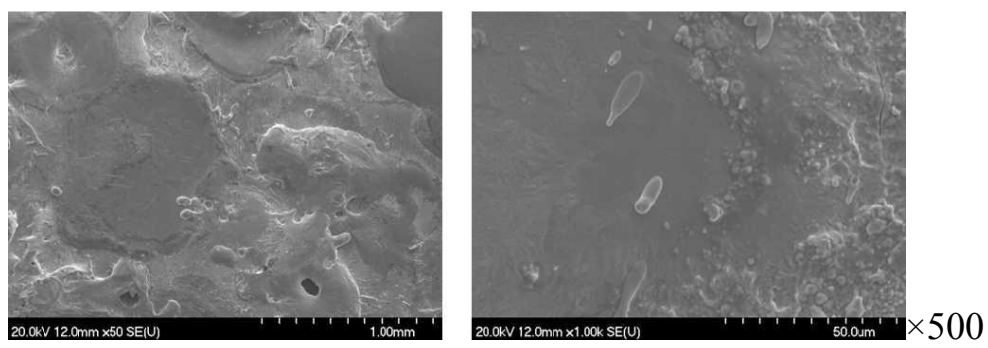

Fig. 4. Sample 2 before testing for exposure to corrosive environment
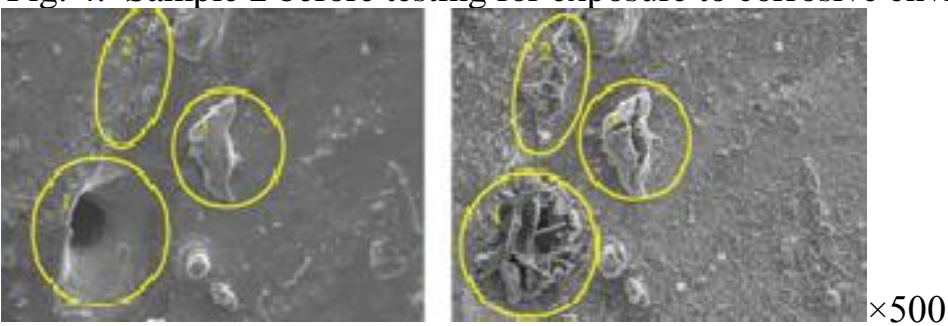

Fig. 5. SEM image of Sample 2 Position 1 in Location 2: $\mathrm{a}-$ before and $\mathrm{b}-$ after the test

The surface of the sample reinforced by ESA with $15 \mathrm{X} 11 \mathrm{M} \Phi$ steel is also heterogeneous, as on sample 2, which is typical for electrospark surface treatment.

Although corrosion affected the entire surface, a relatively thick layer of corrosion was formed with significant local differences. In fig. 6 this is illustrated in more detail. At the edges of the holes, the accumulation of a corrosive product is appear: the deposition of a certain amount of salt, oxide in the holes and ribs.
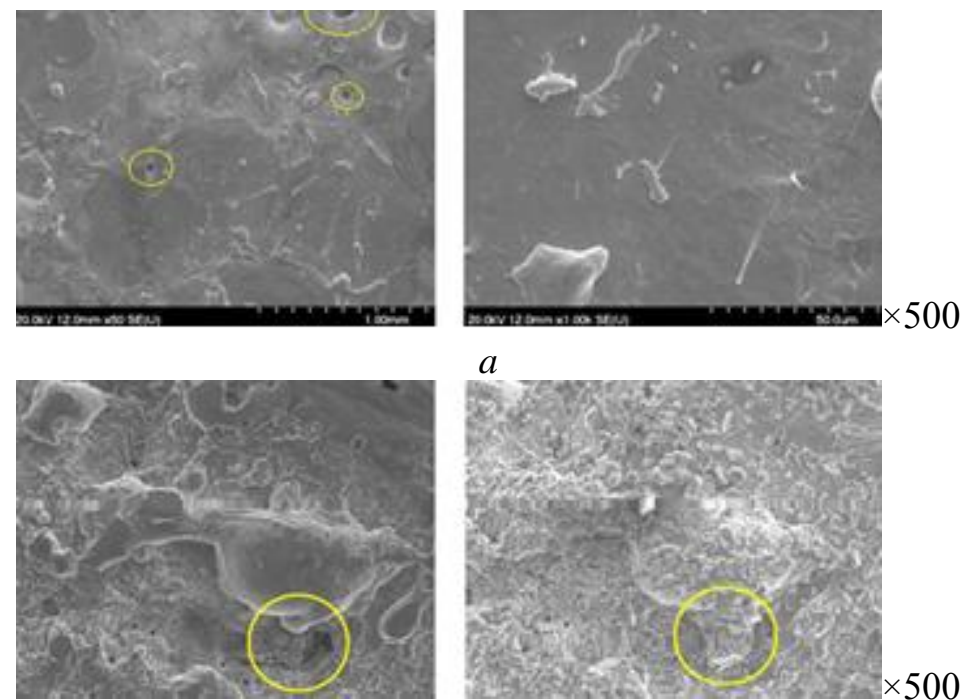

$b$

Fig. 6. SEM image of sample 3: $a$ - before, $b-$ after the test

For electrochemical corrosion tests, electrodes with a geometric surface area of $0.5-$ $1 \mathrm{~cm}^{2}$ made of a blade sample were used. The sides without surface treatment were masked with epoxy adhesive. The measurements were carried out in a nitrogen-oxygen solution, the acidity of which was adjusted to $\mathrm{pH} 9.6$ using ammonia at $25{ }^{\circ} \mathrm{C}$. An oxygen-free ammonia closed system was heated to $50{ }^{\circ} \mathrm{C}$, and after stabilizing the open circuit potential, the resistance of the solution between the working electrode and the comparison electrode (usually 
$2-5 \mathrm{kOhm}$ ) was first determined by measuring the impedance. Then cathodic and anode polarization was performed from the open circuit potential in the range of $\pm 250 \mathrm{mV}$. Depending on the current values, the potential data was adjusted using the ohmic potential drop.

Evans diagrams are plotted and the corrosion rate is determined for each type of reinforcement (table. 2).

Table 2 - Comparison of corrosion indicators of samples

\begin{tabular}{|c|c|c|c|c|c|c|}
\hline Sample & $\begin{array}{c}\text { Reinforcement } \\
\text { method }\end{array}$ & Ekorr & jkorr & $\beta \mathrm{a}$ & $\beta \mathrm{k}$ & Corrosion rate \\
\hline No. & & $\mathrm{mV}$ & $\mathrm{A} \mathrm{cm}^{-2}$ & $\mathrm{mV}$ & $\mathrm{mV}$ & um per year \\
\hline 1 & UHF & -255 & $3.5-10^{-8}$ & 300 & 180 & 0.4 \\
\hline 2 & T15K6 ESA & -602 & $2.3-10^{-6}$ & 220 & 335 & 12.0 \\
\hline 3 & 15 X11MФ ESA & -410 & $4.9-10^{-7}$ & 400 & 220 & 5.6 \\
\hline
\end{tabular}

\section{Conclusions}

Corrosion tests of blade samples were carried out, the leading edges of which are reinforced in three ways: by reinforcing with high-frequency currents, electrospark alloying with T15K6 alloy, and electrospark alloying with 15X1MФШ steel.

Morphological parameters of the surface layers of the samples were determined. Comparison of morphological, compositional and corrosion analysis of samples showed that the sample reinforced with T15K6 alloy by electrospark alloying is the worst in terms of corrosion resistance.

In fact, the uneven corrosion of samples reinforced by electrospark alloying is higher compared to samples reinforced by highfrequency currents. In these samples, sensitivity to local corrosion was detected, so it is important to obtain layers with the maximum density of sections modified by the alloying electrode when performing the technological operation of electrospark alloying.

According to the results of the tests, the layer reinforced by quenching with high-frequency currents has the lowest rate of corrosion, and the layer reinforced by electrospark alloying with T15K6 hard alloy has the highest rate. The corrosion rate of a layer reinforced with electrospark alloying with $15 \mathrm{X} 11 \mathrm{M} \Phi$ steel is 2.1 less than that of a layer reinforced with T15K6 alloy.

\section{Bibliography}

1. Shubenko A. L. Dropstroke erosion of blades devices of steam turbines. Forecast and methods of safeguard / A. L. Shubenko, A. E. Kovalskii. Bulletin of the National Technical University "KhPI": proceedings Ser. Power and Heat Engineering Processes and Equipment. Kharkiv:
NTU "KHPI". 2012. No. 7. P. 76-87.

2. Assessment of protective properties of multi-layer coatings for steam turbine blades / Sevidova E. K., Matsevityi V. M., Kazak I. B., Vakulenko K. V. Electronic Processing of Materials. 2007. No. 6. P. 4-9.

3. Bashar O. Enhancement of Corrosion Resistance in Steam Turbines Blades. Nanoparticles Coatings Al-Nahrain Journal for Engineering Sciences (NJES). Vol. 20 No.5. 2017 P.11721181.

4. Vinogradova S. S., Kaidrikov R. A., Zhuravlev B. L. Calculation of corrosion indicators and parameters of corrosion systems. Kazan: KNRTU, 2013. $176 \mathrm{p}$.

5. Mingazhev A. D., Novikov A. V., Krioni N. K., Bekishev R. R. Protective coating for steam turbine blades. Oil and Gas Engineering Electronic Scientific Journal . 2014. No.4. 257 p.

6. Hardening of leading edges of turbine blades by electrospark alloing / Kalinina N. E., Hlushkova D. B., Hrinchenko O. D., Nosova T. V., Reznikov A. A. Problem of Atomic Science and Technology. 2019. 120(2). P. 151-154.

7. Increase of wear resistance of the critical parts of hydraulic hammer by means of ion-plasma treatment / Hlushkova D. B., Ryzhkov Y. V., Kostina L. L., Demchenko S. V. Problem of Atomic Science and Technology. 2018. 113(1). P. 208-211.

Hlushkova Diana, Head of Chair of Technology of Metals and Materials, D. Sc. (Eng.),

Bagrov Valeriy, Associate Professor Chair of Technology of Metals and Materials, Ph.D. (Eng.), havetabanca@ukr.net,

Hrinchenko Elena, Associate Professor, Ph.D. (Eng.),

Applicant Chair of Technology of Metals and Materials,

Stepaniyk Andrey, assistance Chair of Technology of Metals and Materials, 
Hnatiyk Anastasiya, student Chair of Technology of Metals and Materials

Kharkiv National Automobile and Highway University, 25, Yaroslava Mudrogo str., Kharkiv, 61002, Ukraine,

Kalinina Nataliya, D. Sc. (Eng.), professor, kalinina.dnu@gmail.com.

Dnipro National University, Potter, Olesya 72, Gagarina avenue, Dnipro, 49000

\section{Підвищення корозійної стійкості лопаток турбін}

Анотація. Надійність роботи лопаткового апарата парових турбін значною мірою визначає роботу турбіни загалом. Результати наукових досліджень демонструють, щзо поверхневе спрачювання робочих лопаток у волого-паровому потоці викликано поєднанням корозіі $i$ каплеударной ерозії. Наявність у робочому тілі хімічних елементів $i$ сполук інтенсифікують прочес зношення лопаток. Відчутний вплив на характеристики зношення надає значення $\mathrm{pH}$ робочого середовища, яке може значно коливатися в прочесі експлуатації. Проаналізовано вплив способів зміинення вхідних кромок лопаток парових турбін зі сталі 15Х11МФ на корозійну стійкість. Здійснено корозійні випробування зразків лопаток, вхідні кромки яких зміцнені трьома способами: зміцненням струмами високої частоти, електроіскровим легуванням сплавом Т15К6, електроіскровим легуванням сталлю 15Х1МФ. За результатами експериментів найменшу швидкість корозії має шар, зміцнений загартуванням струмами високої частоти, найбільшу - шар, зміцнений електроіскровим легуванням твердим сплавом Т15Кб. Швидкість корозіі шару, зміцненого електроіскровим легуванням сталлю $15 X 11 M \Phi$, в 2,1 раза менше, ніж шару, зміиненого сплавом Т15Кб.

Ключові слова: лопатки турбін, корозія, ерозія, електроіскрове легування, зміцнений шар.

Глушкова Діана Борисівна, д.т.н., проф., зав. кафедри технології металів та матеріалознавства, 057-707 37-29, diana.borisovna@ gmail.com,

Багров Валерій Анатолійович, к.т.н., доцент кафедри технології металів та матеріалознавства, havetabanca@ukr.net,

Степанюк Андрій Іванович, асистент, кафедра технології металів та матеріалознавства, тел. +38 097-525-85-13, dioxid26@ meta.ua,

Гнатюк Анастасія Анатоліївна, студент кафедри технології металів та матеріалознавства, Гринченко Олена Дмитровна, к.т.н., здобувач кафедри технології металів та матеріалознавства, Харківський національний автомобільнодорожній університет, Україна

Калініна Наталія Свграфівна, д.т.н., професор кафедри технології матеріалів, тел. 095-550-28-00, kalinina.dnu@gmail.com,

Дніпровський національний університет імені Олеся Гончара, пр. Гагаріна, 72, м. Дніпро, 49010, Україна. 